\title{
Przyczyny pożarów i skuteczność systemu ochrony przeciwpożarowej Lasów Państwowych w latach 2010-2019 na przykładzie Nadleśnictwa Kielce
}

\section{The causes of fires and the effectiveness of the fire protection system of the State Forests in 2010-2019 on the example of the Kielce Forest District}

\begin{abstract}
Zarys treści
Celem opracowania jest ustalenie przyczyn pożarów lasów i skuteczności systemu przeciwpożarowego Lasów Państwowych na terenie Nadleśnictwa Kielce. Dokonano analizy porównawczej przebiegu wybranych danych meteorologicznych sprzyjających powstawaniu pożarów z danymi dotyczącymi pożarów lasów (bazy TETRAX elektronik, SILP, Llas.2) w latach 2010-2019, ze szczególnym uwzględnieniem pożarów o nieustalonych przyczynach. Pozwoliło to ustalić dominację czynników antropogenicznych nad naturalnymi w wywoływaniu pożarów. Stwierdzono dużą skuteczność systemu przeciwpożarowego, co związane jest m.in. z gęstą siecią dróg i brakiem większych, zwartych kompleksów leśnych.
\end{abstract}

Słowa kluczowe Pożary lasów, system ochrony przeciwpożarowej, Nadleśnictwo Kielce, warunki meteorologiczne, ściółka leśna.

Abstract

The aim of the study is to determine the causes of the forest fires and the effectiveness of the State Forests fire protection system in Kielce Forest District. A comparative analysis of the course of selected meteorological data favoring the occurrence of fires and forest fires data (databases TETRAX electronic, SILP, Llas.2) in 2010-2019, with particular emphasis on fires with unknown causes was obtained and analyzed. This allowed to establish the dominance of anthropogenic over natural factors in forest fires ignition. The high effectiveness of the fire protection system was confirmed, which is related to i.e. with a dense network of roads and the lack of large, compact forest complexes.

Keywords

Forest fires, fire protection system, Kielce Forest District, meteorological conditions, duff.

\section{Wprowadzenie}

Jednym z najbardziej niebezpiecznych zjawisk naturalnych jest pożar lasu. Pożary naturalne w ostatnich dziesięcioleciach, na skutek zmian klimatycznych, a także gospodarki leśnej (np. sztuczne obsiewy o dużej ilości drzew na jednostkę powierzchni, nagromadzenie martwego drewna w obszarach chronionych, występowanie jedynie małych pożarów i zapobieganie dużym), stają się coraz częstsze, coraz bardziej gwałtowne i destrukcyjne. Rocznie trawią 4\% obszaru lądów, a największe w ostatnich latach wybuchły w Kalifornii i Irlandii Północnej (2018), Amazonii i Australii (2019). Skala zjawisk i ich częstość spowodowały, że Pyne (2015) proponuje nazwanie obecnego okresu pirocenem, a wagę zjawiska podkreśla uruchomienie przez NASA i NOAA projektu badawczego FIREX-AQ, którego celem jest określenie składu dymów z pożarów biomasy i ich wpływu na zdrowie człowieka (McClure, Jaffe 2018; Prunicki i in. 2019; Dickman 2020).

Badania zagadnień związanych z pożarami lasów były podejmowane wielokrotnie już wcześniej, zarówno w Polsce (m.in. Szczygieł 1982, 1985, 1987, 1988, 1991c, 1992, 2012; Ubysz 1992, 1994; Fraszewski 1994; Santorski 1994ab, 1999; Santorski, Mycke-Dominko 1998; Karlikowski i in. 1998; Wiśniewski 2001; Szczygieł i in. 2007, 2008; Wiłkomirski, Gutry 2010; Haze i in. 2012; Bogacz i in. 2011, 2014), jak i na świecie (m.in. Parminter 1983; Dumontet i in. 1996; Preston, Baldwin 1999; Odion, Davis 2000; Pierce i in. 2004; Certini 2005; Miller, Thode 2007; Xue, Li, Chen 2014; Feurdean i in. 2020; Gallagher i in. 2020). Wielu badaczy próbowało ustalić wpływ czynników naturalnych, jak warunki pogodowe (m.in. Karlikowski, Łonkiewicz 1975; Szczygieł 1991ab) lub antropogenicznych (np. Szczygieł 1977; Sakowska 1994; Ciura 2018) na powstawanie pożarów lasów.

Naturalne przyczyny zapłonu mają miejsce niezwykle rzadko i tylko przy sprzyjających warunkach meteorologicznych (uderzenie pioruna, susze i upały) oraz typu kompleksu leśnego. Warunki pogodowe determinują wilgotność ściółki i są to dwa główne czynniki, od których zależy podatność lasów na pożary. Zapłon i spalanie ściółki leśnej w lasach szerokości umiarkowanych są jak dotąd słabo 
poznane. Nie ulega wątpliwości, że długotrwały brak opadów wpływa na spadek wilgotności ściółki. Sprzyja temu również wysoka temperatura powietrza i na podstawie tych dwóch elementów określa się w polskim leśnictwie zagrożenie pożarowe. Badania prowadzone w Instytucie Badawczym Leśnictwa (Szczygieł 2012) wykazały, że „pogodę pożarową” przy której obserwuje się wzrost częstotliwości pożarów lasu charakteryzuje: brak opadu atmosferycznego, małe zachmurzenie, wysoka temperatura powietrza i niska wilgotność względna powietrza. W Polsce zdecydowana większość (90\%) pożarów lasów wybucha w dni, gdy wilgotność ściółki jest niższa niż 15\% (Kaczmarowski 2016). W warunkach naszego klimatu wykluczono praktycznie zjawisko samozapłonu ściółki (Szczygieł 2010), choć występuje ono prawdopodobnie w borach Kanady (Kreye i in. 2013), a powszechnie w eukaliptusowych lasach Australii (Jones i in. 1990).

Ściółka leśna warunkuje możliwość powstania wielu pożarów i wpływa na ich dalsze rozprzestrzenianie się. Intensywność rozszerzania się pożaru zależy przede wszystkim od ilości i rodzaju materiałów palnych pokrywających powierzchnię gleby oraz prędkości wiatru. Płonące igliwie to doskonały nośnik ognia, który wydzielając ciepło szybko przesusza sąsiedni materiał roślinny. Składnikami ściółki są również drobne gałązki, złuszczona korowina i szyszki. Dojrzałe otwarte szyszki mają rozległą powierzchnię styku z powietrzem. Ich wilgotność jest niższa niż igliwia znajdującego się w ściółce. Sosnowe igliwie i szyszki zawierają olejki eteryczne, z których większość stanowią palne węglowodory monoterpenowe i pineny (Nurzyńska-Wierdak 2015). Według pirologii leśnej zdecydowana większość (90\%) pożarów lasów wybucha w dni, gdy wilgotność ściółki jest niższa niż 15\% (dlatego zakaz wstępu do lasu wprowadza się przy trzecim stopniu zagrożenia pożarowego, jeśli przez kolejnych 5 dni wilgotność ściółki mierzona o godzinie 9:00 jest niższa niż 10\%). Ściółka sosnowa staje się praktycznie niepalna przy wilgotności równej $28 \%$. Najlepsze właściwości palne ma ściółka sosnowa. Ściółka pozostałych gatunków iglastych (świerk, jodła, modrzew), z uwagi na zwięzłą strukturę, zapala się gorzej od sosnowej. Dobrym materiałem palnym jest także ściółka bukowa po okresie wegetacji, tj. późną jesienią (Kaczmarowski 2016).

Wśród naturalnych przyczyń powstawania pożarów leśnych podawane są często wyładowania atmosferyczne. Według danych z Lasów Państwowych przyczyna ta stanowi zaledwie $2 \%$ wszystkich pożarów w państwowych lasach Polski (Marchelek 2020). Z danych Unii Europejskiej w Szwecji wyładowania atmosferyczne powodują około 4\% pożarów leśnych (Ciura 2018). Realne zagrożenie stwarzają wyładowania atmosferyczne bez opadów deszczu, gdyż te ostatnie zwykle gaszą pożar w zarodku.

Przyczyny pożarów lasów są często trudne lub niemożliwe do ustalenia, ale w tym przypadku prawdopodobieństwo naturalnego zapłonu jest niewielkie. Dlatego bezpośredni i pośredni wpływ człowieka na wywoływanie pożarów lasów jest brany najczęściej pod uwagę (Szczygieł 2012; Ciura 2018) i wydaje się czynnikiem dominującym na całym świecie. Jednak jednoznacznie udaje się to ustalić jedynie w przypadku złapania podpalacza na gorącym uczynku.

Niezależnie od przyczyny, pożary lasów mogą strawić w szybkim tempie wiele hektarów podszycia doprowadzając do zmian w środowisku leśnym. Często odbudowa zniszczonego lasu jest długotrwała i kosztowna, a zmiany na przestrzeni wielu lat zachodzą również w glebie zmieniając jej właściwości (Szczygieł 1989; Kutiel, Shaviv 1992; Przepióra i in. 2017).

Każde państwo posiadające na swoim terenie rozległe kompleksy leśne stara się je zabezpieczyć przed niszczącymi skutkami zjawisk naturalnych, jak i działalnością człowieka. Ochroną i gospodarką leśną w Polsce zajmują się Lasy Państwowe. W nadleśnictwach stosowany jest system przeciwpożarowy zapobiegający rozwinięciu się dużych pożarów na terenach leśnych i obszarach bezpośrednio do nich przyległych.

\section{Cel i metody}

Celem opracowania jest ustalenie przyczyn pożarów i skuteczności systemu przeciwpożarowego Lasów Państwowych w latach 2010-2019 na przykładzie Nadleśnictwa Kielce (Ryc. 1). Szczególną uwagę poświęcono pożarom o nieustalonych przyczynach, w szczególności rozpatrzeniu w jakich warunkach pogodowych i synoptycznych wystąpiły takie pożary oraz jaką rolę w ich powstawaniu odgrywała wilgotność ściółki. To studium przypadku można odnieść do innych nadleśnictw w kraju, a wnioski wynikające z artykułu, oprócz znaczenia naukowego, mogą mieć zastosowanie również w praktyce.

Dokonano analizy przebiegu wybranych danych meteorologicznych w badanym okresie, które mogły sprzyjać powstawaniu pożarów. Dane podstawowe, takie jak średnie miesięczne i roczne: temperatury powietrza, maksymalne temperatury powietrza, opady, liczba dni upalnych pozyskano ze stacji pomiarowej Kielce-Suków oraz bazy danych IMGW. Na podstawie cogodzinnych danych meteorologicznych z tej stacji analizowano przed wybuchem pożaru stan i rodzaj zachmurzenia, występowanie opadów lub wyładowań atmosferycznych. Z danych liczbowych określono temperaturę maksymalną i wilgotność względną minimalną powietrza przed godziną zgłoszenia pożaru. Wyznaczono dwa przedziały termiczne sprzyjające pożarom: $25,1-30,0^{\circ} \mathrm{C}$ jako gorąco oraz powyżej $30,0^{\circ} \mathrm{C}$ jako upalnie. Na podstawie doświadczeń metodycznych z Puszczy Białowieskiej (Żarnowiecki 1991, 1994) dla minimalnej wilgotności względnej powietrza przyjęto dwa przedziały: sucho $30-49 \%$ i bardzo sucho poniżej 30\% (http://www. danepubliczne.imgw.pl).

Dla dni z pożarami o nieustalonych przyczynach dodatkowo określano sytuację synoptyczną wykorzystując klasyfikację Niedźwiedzia (1981) na podstawie codziennych map dolnych Europy (http://www.knmi.nl).

Z bazy „TRAX elektronik” dla stacji w Jędrzejowie (http://www.traxelektronik.pl) pozyskano dane na temat średniej temperatury przy powierzchni gruntu na wyso- 
kości $5 \mathrm{~cm}$ oraz średniej wilgotności ściółki w ujęciu miesięcznym. Z 54 pożarów o niewyjaśnionych przyczynach połączono $w$ jeden te, które pojawiły się jednocześnie w bezpośrednim sąsiedztwie, np. w tym samym oddziale. Uzyskano w ten sposób 49 pożarów o niewyjaśnionych przyczynach zapłonu. Pomiary wilgotności ściółki uzyskano w ujęciu dziennym z godziny 8:00 i 13:00. Ponieważ w dwóch przypadkach nie ustalono wilgotności ściółki, ograniczyło to dane do 47 dat. Dla dni z pożarem o nieustalonych przyczynach wydzielono 2 klasy wilgotności ściółki: powyżej 30\% - ściółka niepalna i poniżej 15\% - bardzo sucha.

Dane źródłowe dotyczące pożarów w Nadleśnictwie Kielce w latach 2010-2019 pozyskano z cyfrowej bazy danych „System Informacji Lasów Państwowych - SILP,
Llas.2" oraz systemu „Banku Danych o Lasach”. Opracowano mapę z lokalizacją i klasyfikację wszystkich 92 pożarów (140 raportów) w formie tabelarycznej i graficznej z uwzględnieniem ich rozmiaru (powierzchnia w ha) i przyczyny powstania.

Dane meteorologiczne porównano z danymi pożarowymi, m.in. z lokalizacją pożarów względem infrastruktury drogowej i zabudowy, co umożliwiło prześledzenie przyczyn i interpretację zmian w występowaniu pożarów lasów na przestrzeni ostatniego dziesięciolecia.

Szczegółowej analizie poddano także sposób wykrycia oraz czas reakcji służb gaśniczych i ugaszenia ognia. Pozwoliło to na zweryfikowanie skuteczności systemu zwalczania pożarów.

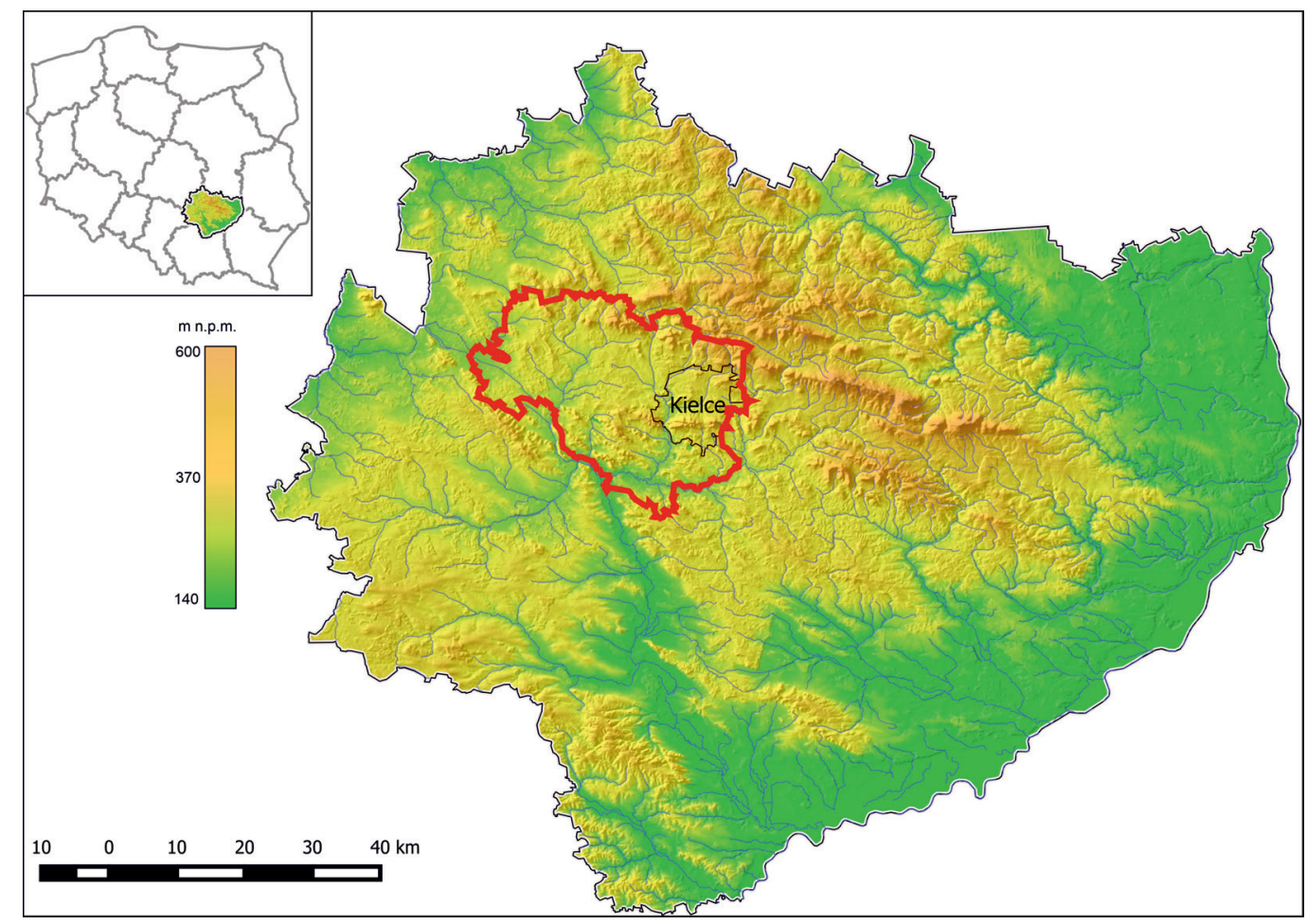

Ryc. 1. Położenie obszaru badań na numerycznym modelu terenu (NMT) województwa świętokrzyskiego, oprac. M. Frączek na podstawie danych pozyskanych z CODGiK (MGGP Aero, Nr GI-FOTO.703.44.2014)

Fig. 1. Location of the research area on the Świętokrzyskie Voivodeship digital elevation model (DEM), ed. by M. Frączek based on the data obtained from CODGiK (MGGP Aero, No. GI-FOTO.703.44.2014)

\section{Obszar badań}

Nadleśnictwo Kielce położone jest w centralnej części województwa świętokrzyskiego (Ryc. 1) i podlega jurysdykcji Regionalnej Dyrekcji Lasów Państwowych w Radomiu. Leży ono w mezoregionie fizycznogeograficznym Góry Świętokrzyskie (342.34-5) (Kondracki 1977, 2002).

Według regionalizacji przyrodniczo-leśnej (Sikorska 2004) lasy tego nadleśnictwa znajdują się w krainie Małopolskiej (VI), dzielnicy Gór Świętokrzyskich (VI.2), mezoregionach Puszczy Świętokrzyskiej (VI.2.a) i Łysogórskim (VI.2.b). Obszar nadleśnictwa wynosi około 166 km², a przeciętna zasobność drzewostanów wynosi 285 m³/ha. Badany obszar charakteryzuje się przewagą siedlisk bo- rowych oraz średnim wiekiem sosny około 70 lat. Ponad $17 \%$ obszarów leśnych to lasy gospodarcze, $80 \%$ jest objęta ochroną, a ponad $2 \%$ znajduje się w granicach rezerwatów (http://www.kielce.radom.lasy.gov.pl).

W ostatnich latach granice administracyjne Nadleśnictwa Kielce zostały zmienione i w jego północnej części dokonano reorganizacji jednostek. W badanym okresie zlikwidowano Leśnictwo Łopuszno, którego obszar włączono do sąsiednich jednostek organizacyjnych oraz wydzielono nowe Leśnictwo Zawada, które obejmuje dużą część obszaru Leśnictwa Słowik. Obecnie Nadleśnictwo Kielce jest podzielone na 12 leśnictw: Dyminy, Słowik, Bilcza, Podzamcze, Dąbrowa, Gruchawka, Oblęgorek, Niewachlów, Dobrzeszów, Sojawa, Czartoszowy oraz Zawada. 
4. Warunki meteorologiczne w analizowanym okresie

W latach 2010-2019 widoczny jest wyraźny wzrost średniej rocznej temperatury. Różnica pomiędzy 2010 i 2019 rokiem wynosi ok. $2,5^{\circ} \mathrm{C}$ (Tab. 1). Widoczny jest bardzo wyraźny wzrost temperatury miesięcy zimowych, co powoduje skrócenie okresu utrzymywania się pokrywy śnieżnej (ciepłe i suche zimy). Tendencja ta jest również znacząca w przypadku średniej maksymalnej temperatury w lecie. Rok 2015 charakteryzował się największą licz- bą dni upalnych (24), które wystąpiły w lipcu i sierpniu. W badanym okresie sumy roczne opadów osiągnęły znaczną różnicę ok. $250 \mathrm{~mm}$ pomiędzy rokiem najbardziej wilgotnym 752,6 $\mathrm{mm}$ (2014) a najsuchszym 486,7 mm (2018).

$Z$ danych IMGW (Tab. 1) wynika, że rok 2018 jest 2-gim najcieplejszym rokiem w latach 2010-2019 średniej temperatury powietrza i niezwykle niską sumą opadów w kwietniu, w którym wystąpiło najwięcej pożarów lasów na terenie Nadleśnictwa Kielce w analizowanym dziesięcioleciu.

Tabela 1. Dane meteorologiczne z lat 2010-2019 ze stacji Kielce-Suków (http://www.meteomodel.pl)

Table 1. Meteorological data for 2010-2019 from the Kielce-Suków station (http://www.meteomodel.pl)

\begin{tabular}{|c|c|c|c|c|c|c|c|c|c|c|c|c|c|}
\hline \multicolumn{14}{|c|}{ Średnia temperatura powietrza/Average air temperature $\left[{ }^{\circ} \mathrm{C}\right]$} \\
\hline $\mathrm{R} / \mathrm{M} \mathrm{Y} / \mathrm{M}$ & 1 & II & III & IV & V & $\mathrm{VI}$ & VII & VIII & IX & $\mathrm{X}$ & $\mathrm{XI}$ & $\mathrm{XII}$ & $I-X I I$ \\
\hline 2010 & $-7,3$ & $-2,1$ & 2,2 & 8,3 & 13,0 & 16,9 & 20,3 & 18,5 & 11,8 & 5,1 & 5,8 & $-5,4$ & 7,3 \\
\hline 2011 & $-1,5$ & $-3,5$ & 2,7 & 9,9 & 13,3 & 17,9 & 17,3 & 18,2 & 14,4 & 7,8 & 2,0 & 1,5 & 8,3 \\
\hline 2012 & $-1,9$ & $-7,3$ & 3,8 & 8,9 & 14,3 & 17,1 & 20,1 & 18,6 & 14,0 & 7,9 & 4,8 & $-3,4$ & 8,1 \\
\hline 2013 & $-3,3$ & $-1,2$ & $-1,9$ & 7,9 & 14,1 & 17,7 & 18,9 & 18,5 & 11,6 & 9,4 & 4,9 & 1,0 & 8,1 \\
\hline 2014 & $-2,0$ & 1,2 & 5,7 & 9,7 & 13,3 & 15,5 & 19,8 & 17,1 & 14,3 & 9,0 & 5,0 & 0,5 & 9,1 \\
\hline 2015 & 0,6 & 0,1 & 4,0 & 7,5 & 12,3 & 16,4 & 19,4 & 21,6 & 14,8 & 6,8 & 4,4 & 3,4 & 9,3 \\
\hline 2016 & $-3,1$ & 3,1 & 3,6 & 8,5 & 14,3 & 18,5 & 18,9 & 17,4 & 15,0 & 7,1 & 2,8 & $-0,1$ & 8,8 \\
\hline 2017 & $-6,1$ & $-1,2$ & 5,1 & 6,7 & 13,3 & 17,9 & 18,4 & 19,4 & 13,5 & 9,2 & 3,7 & 1,3 & 8,4 \\
\hline 2018 & 0,3 & $-4,0$ & $-0,2$ & 13,0 & 16,8 & 18,3 & 19,6 & 19,7 & 14,8 & 9,7 & 3,9 & 0,6 & 9,4 \\
\hline 2019 & $-2,8$ & 2,0 & 4,8 & 9,6 & 12,5 & 21,6 & 18,2 & 19,7 & 13,6 & 9,6 & 5,9 & 2,1 & 9,7 \\
\hline \multicolumn{14}{|c|}{ Średnia temperatura maksymalna/Average maximum temperature $\left[{ }^{\circ} \mathrm{C}\right]$} \\
\hline $\mathrm{R} / \mathrm{M} \mathrm{Y} / \mathrm{M}$ & I & II & III & IV & $\mathrm{V}$ & $\mathrm{VI}$ & VII & VIII & IX & $\mathrm{X}$ & $\mathrm{XI}$ & $\mathrm{XII}$ & $I-X I I$ \\
\hline 2010 & $-4,4$ & 1,6 & 7,6 & 14,6 & 17,5 & 22,1 & 26,1 & 24,5 & 16,7 & 10,5 & 9,3 & $-2,3$ & 12,0 \\
\hline 2011 & 0,9 & 0,1 & 8,5 & 16,4 & 19,8 & 23,8 & 22,4 & 24,6 & 21,3 & 13,2 & 6,5 & 4,1 & 13,5 \\
\hline 2012 & 0,6 & $-3,1$ & 9,7 & 15,0 & 20,7 & 22,5 & 26,6 & 25,1 & 20,6 & 13,3 & 8,0 & $-0,6$ & 13,2 \\
\hline 2013 & $-1,3$ & 1,0 & 1,8 & 13,2 & 19,5 & 22,8 & 25,5 & 25,5 & 16,6 & 15,2 & 8,0 & 4,3 & 12,7 \\
\hline 2014 & 0,6 & 6,4 & 11,3 & 15,6 & 18,8 & 21,4 & 25,8 & 22,7 & 20,1 & 14,3 & 7,9 & 3,0 & 14,0 \\
\hline 2015 & 3,3 & 4,0 & 9,7 & 14,0 & 18,1 & 22,2 & 26,4 & 29,2 & 20,1 & 12,1 & 8,2 & 6,9 & 14,5 \\
\hline 2016 & 0,1 & 6,7 & 7,9 & 14,1 & 20,4 & 25,1 & 25,2 & 24,1 & 22,1 & 10,6 & 5,8 & 2,6 & 13,7 \\
\hline 2017 & $-1,6$ & 2,7 & 10,3 & 12,0 & 19,0 & 24,5 & 25,1 & 26,3 & 18,1 & 13,2 & 6,4 & 3,8 & 13,3 \\
\hline 2018 & 3,0 & $-0,9$ & 4,8 & 20,6 & 22,8 & 24,8 & 25,6 & 26,1 & 21,7 & 16,4 & 8,0 & 2,6 & 14,6 \\
\hline 2019 & $-0,2$ & 7,4 & 10,9 & 15,5 & 17,4 & 27,8 & 24,9 & 25,9 & 19,4 & 16,4 & 9,6 & 5,2 & 15,0 \\
\hline
\end{tabular}




\begin{tabular}{|c|c|c|c|c|c|c|c|c|c|c|c|c|c|}
\hline \multicolumn{14}{|c|}{ Liczba dni upalnych/Number of hot days } \\
\hline $\mathrm{R} / \mathrm{M} \mathrm{Y} / \mathrm{M}$ & 1 & II & III & IV & V & $\mathrm{VI}$ & VII & VIII & IX & $x$ & $\mathrm{XI}$ & XII & I-XII \\
\hline 2010 & 0 & 0 & 0 & 0 & 0 & 1 & 5 & 1 & 0 & 0 & 0 & 0 & 7 \\
\hline 2011 & 0 & 0 & 0 & 0 & 0 & 0 & 1 & 1 & 0 & 0 & 0 & 0 & 2 \\
\hline 2012 & 0 & 0 & 0 & 0 & 0 & 1 & 6 & 4 & 0 & 0 & 0 & 0 & 11 \\
\hline 2013 & 0 & 0 & 0 & 0 & 0 & 1 & 3 & 5 & 0 & 0 & 0 & 0 & 9 \\
\hline 2014 & 0 & 0 & 0 & 0 & 0 & 0 & 1 & 2 & 0 & 0 & 0 & 0 & 3 \\
\hline 2015 & 0 & 0 & 0 & 0 & 0 & 0 & 7 & 15 & 2 & 0 & 0 & 0 & 24 \\
\hline 2016 & 0 & 0 & 0 & 0 & 0 & 5 & 2 & 0 & 0 & 0 & 0 & 0 & 7 \\
\hline 2017 & 0 & 0 & 0 & 0 & 0 & 1 & 2 & 5 & 0 & 0 & 0 & 0 & 8 \\
\hline 2018 & 0 & 0 & 0 & 0 & 0 & 1 & 1 & 3 & 0 & 0 & 0 & 0 & 5 \\
\hline 2019 & 0 & 0 & 0 & 0 & 0 & 5 & 3 & 1 & 0 & 0 & 0 & 0 & 9 \\
\hline \multicolumn{14}{|c|}{ Suma opadów/Total rainfall [mm] } \\
\hline R/M Y/M & 1 & $\|$ & III & IV & v & $\mathrm{VI}$ & VII & VIII & IX & $x$ & XI & XII & I-XII \\
\hline 2010 & 27,9 & 32,0 & 35,2 & 18,3 & 129,4 & 79,4 & 95,9 & 126,8 & 104,9 & 7,2 & 47,0 & 40,3 & 744,3 \\
\hline 2011 & 26,5 & 21,1 & 8,6 & 28,5 & 48,1 & 56,4 & 241,4 & 40,7 & 4,6 & 24,4 & 0,3 & 36,6 & 537,2 \\
\hline 2012 & 46,9 & 23,2 & 22,1 & 32,9 & 63,0 & 64,2 & 63,9 & 38,9 & 24,3 & 103,0 & 33,4 & 26,3 & 542,1 \\
\hline 2013 & 64,9 & 29,2 & 48,7 & 17,3 & 133,7 & 92,8 & 12,1 & 26,9 & 71,4 & 10,9 & 57,9 & 25,8 & 591,6 \\
\hline 2014 & 49,3 & 21,2 & 58,6 & 35,5 & 122,1 & 72,2 & 162,9 & 94,4 & 33,5 & 37,3 & 28,2 & 37,4 & 752,6 \\
\hline 2015 & 43,9 & 27,8 & 34,3 & 26,4 & 107,6 & 60,9 & 50,6 & 11,7 & 72,5 & 32,9 & 68,9 & 21,0 & 558,5 \\
\hline 2016 & 32,9 & 96,2 & 30,7 & 63,8 & 21,8 & 35,0 & 99,6 & 60,0 & 37,0 & 61,4 & 29,3 & 51,8 & 619,5 \\
\hline 2017 & 17,9 & 30,0 & 36,0 & 104,5 & 45,5 & 21,9 & 72,1 & 61,1 & 130,6 & 93,2 & 55,6 & 43,4 & 711,8 \\
\hline 2018 & 25,6 & 16,9 & 26,0 & 8,9 & 46,5 & 43,2 & 114,5 & 71,1 & 14,7 & 41,2 & 4,8 & 73,3 & 486,7 \\
\hline 2019 & 55,4 & 22,6 & 42,6 & 41,5 & 125,7 & 28,7 & 64,1 & 135,3 & 63,0 & 33,3 & 34,6 & 47,1 & 693,0 \\
\hline
\end{tabular}

W badanym okresie odnotowano również wyraźne zmiany warunków meteorologicznych, które mają kluczowy wpływ na występowanie pożarów lasów, m.in. temperaturę przy gruncie oraz wilgotność ściółki (Ryc. 2). W analizach wykorzystano pomiary temperatury $5 \mathrm{~cm}$ nad powierzchnią gruntu. Pomiary temperatury są prowadzone przez cały rok (dane uśrednione dla każdego miesiąca), natomiast wilgotność ściółki mierzona jest od marca do października (okres występowania największych zagrożeń pożarami lasów). Średnia miesięczna maksymalna temperatura na wysokości $5 \mathrm{~cm}$ nad powierzchnią gruntu w okresie letnim wynosi ok. $21,5^{\circ} \mathrm{C}$. Jednak w niektórych latach, np. w kwietniu 2012 r., wartości te są wyraźnie niższe i równocześnie wzrasta wilgotność ściółki. Zwraca uwagę niska wilgotność ściółki w miesiącach letnich (V-VIII) i wiosennych (III-IV). Koresponduje to ze znaczną liczbą pożarów lasów o nieustalonych przyczynach w tych okresach (Tab. 2).

\section{Pożary na analizowanym obszarze}

Na terenie Nadleśnictwa Kielce w latach 2010-2019 wystąpiły 92 pożary (45 ugaszonych w zarodku, 39 małych i 8 średnich) o średniej powierzchni ok. 0,17 ha (Ryc. 3). W cyklu rocznym najczęstsze były wczesnowiosenne pożary lasów (marzec-kwiecień-maj), a najrzadsze pod koniec okresu zagrożenia pożarowego - we wrześniu. Największe pożary (średnie) miały miejsce również w okresie wczesnowiosennym (zazwyczaj kwiecień-maj). Do największego pożaru doszło w kwietniu 2012 roku w Leśnictwie Podzamcze (3,2 ha), natomiast najmniejsze (ugaszone w zarodku) zanotowano w 2016 roku, m.in. w Leśnictwie Niewachlów (około 0,01 ha). Rok 2019 wyróżnia się dużą liczbą pożarów lasów (26 przypadków), podobnie jak lata 2011 i 2018 (po 14 pożarów). Najmniej pożarów wystąpiło w 2014 i 2016 roku (zaledwie po 3 pożary) (Ryc. 4). 


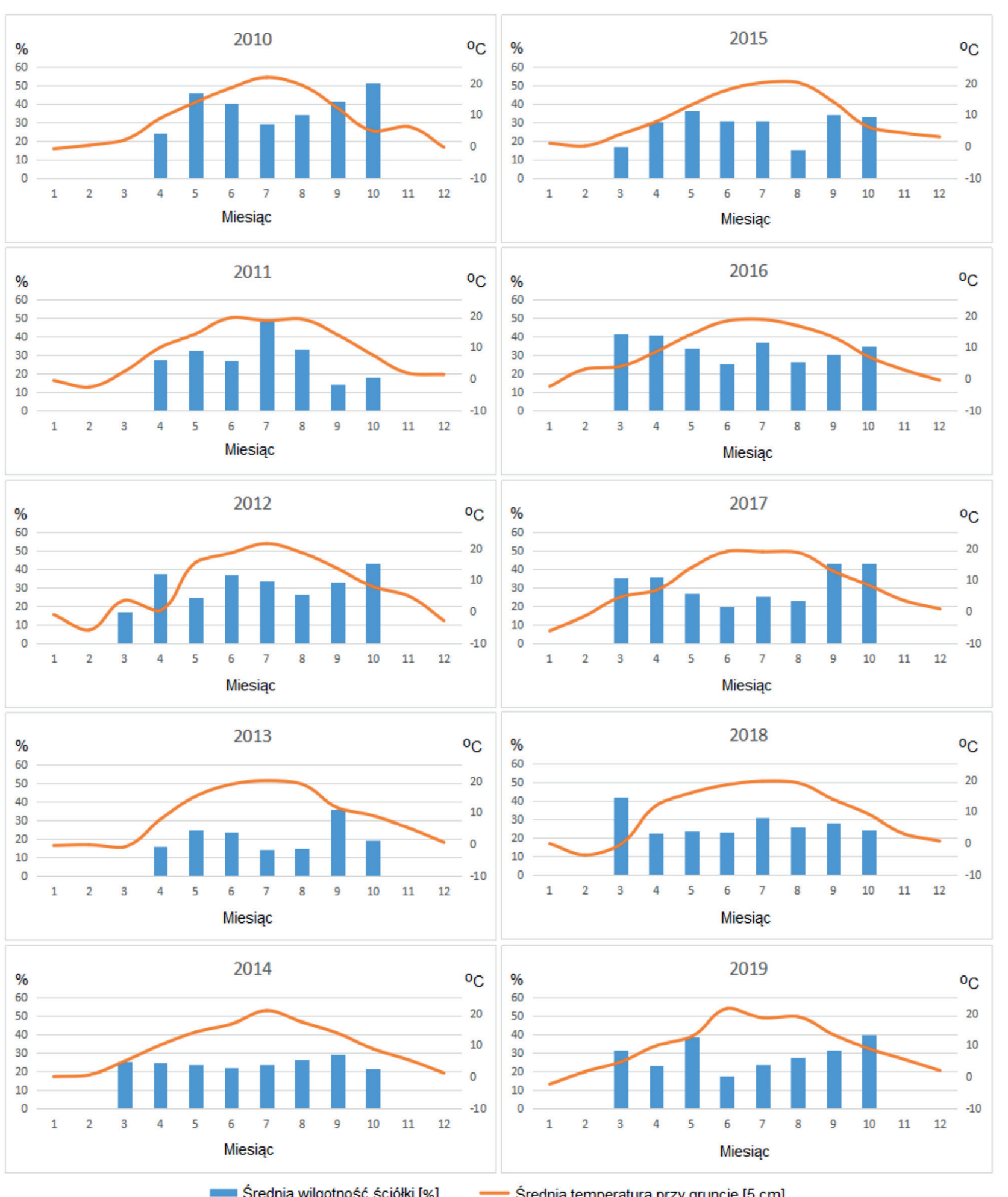

- Średnia wilgotność ściółki [\%]

- Średnia temperatura przy gruncie $[5 \mathrm{~cm}]$

Ryc. 2. Podstawowe dane ze stacji Jędrzejów (las) dotyczące średniej temperatury powietrza $\mathrm{w}^{\circ} \mathrm{C}$ przy gruncie $(5 \mathrm{~cm})$ i wilgotności ściółki (w \%) w latach 2010-2019 (http://www.traxelektronik.pl)

Fig. 2. Basic data from the Jędrzejów station (forest) about avarage air temperature in ${ }^{\circ} \mathrm{C}$ at the ground $(5 \mathrm{~cm})$ and duff moisture (in \%) in 2010-2019 (http://www.traxelektronik.pl) 
Tabela 2. Pożaryo nieustalonych przyczynach (http://www.traxelektronik.pl) w określonych warunkach pogodowo-synoptycznych dla stacji Kielce-Suków (http://www.danepubliczne.imgw.pl, http://www.knmi.nl)

Table 2. Fires of undetermined causes (http://www.traxelektronik.pl) under specific weather and synoptic conditions for Kielce-Suków station (http://www.danepubliczne.imgw.pl, http://www.knmi.nl)

\begin{tabular}{|c|c|c|c|c|c|c|c|}
\hline $\begin{array}{l}\text { Lp. } \\
\text { No. }\end{array}$ & $\begin{array}{l}\text { Data pożaru } \\
\text { Fire date }\end{array}$ & $\begin{array}{c}\text { Leśnictwo (odzdział) } \\
\text { Forestry (sector) }\end{array}$ & $\begin{array}{l}\text { Godz. } \\
\text { zgłoszenia } \\
\text { Notification } \\
\text { time }\end{array}$ & $\begin{array}{c}\text { Drzewostan } \\
\text { i wilgotność ściółki } \\
\text { Forest stade } \\
\text { and duff moisture }\end{array}$ & $\begin{array}{c}\text { Tmax (godz.) } \\
\text { przed pożarem } \\
\text { Tmax (h) } \\
\text { before fire }\end{array}$ & $\begin{array}{c}\text { fmin (godz.) } \\
\text { przed pożarem } \\
\text { fmin(h) } \\
\text { before fire }\end{array}$ & $\begin{array}{c}\text { Sytuacja } \\
\text { synoptyczna } \\
\text { Synoptic } \\
\text { situation }\end{array}$ \\
\hline 1 & $2010-04-26$ & Słowik (97 a) & 16.02 & SO 85 & $21,0(15)$ & $33(15)$ & SE a \\
\hline 2 & $2010-06-12$ & Niewachlów (124 d) & 13.46 & SO KO & $29,6(12)$ & $43(11)$ & SW c \\
\hline 3 & 2010-07-01 & Dobrzeszów (25 g) & 14.15 & SO 70 & $26,4(12)$ & $41(12)$ & SW c \\
\hline 4 & 2010-07-13 & Oblęgorek (85 f) & 14.54 & JD 55 & $29,9(14)$ & $41(13)$ & $\mathrm{E}$ a \\
\hline 5 & 2010-07-20 & Oblęgorek (85 d) & 14.30 & JD 60 & $25,5(14)$ & $63(13)$ & $\mathrm{Ea}$ \\
\hline 6 & $2011-03-25$ & Bilcza (141 c) & brak danych & OL 9 & $9,0(12)$ & $59(12)$ & W c \\
\hline 7 & $2011-04-20$ & Gruchawka (79 d) & 16.50 & SO 70 & $17,7(14)$ & $25(14)$ & $\mathrm{E}$ a \\
\hline 8 & 2011-04-21 & Oblęgorek (88 c) & 19.50 & SO KDO & $20,4(15)$ & $25(15)$ & SE a \\
\hline 9 & 2011-04-28 & Oblęgorek (88 c) & 12.35 & SO KDO & $22,0(11)$ & $29(11)$ & SE a \\
\hline 10 & 2011-04-28 & Niewachlów (108 c) & 16.45 & SO 79 & $22,0(11)$ & $29(11)$ & SE a \\
\hline 11 & 2011-05-22 & Dąbrowa (1 c) & 18.05 & SO 60,28 & $25,3(13)$ & $42(13)$ & $\mathrm{Sa}$ \\
\hline 12 & 2011-05-25 & Dąbrowa (1 p) & 13.50 & SO KO & $16,6(12)$ & $35(12)$ & NW a \\
\hline 13 & 2011-06-05 & Oblęgorek (85 a) & 10.04 & So 70 & $26,3(10)$ & $35(10)$ & $\mathrm{Sa}$ \\
\hline 14 & 2011-06-05 & Oblęgorek (83 c) & 16.05 & JD 60, SO KO & $27,8(14)$ & $32(15)$ & SE a \\
\hline 15 & 2011-06-27 & Oblęgorek (84 d) & 11.30 & JD 55 & $19,5(11)$ & $37(11)$ & $\mathrm{Na}$ \\
\hline 16 & 2011-09-11 & Dyminy (11 a) & 19.34 & SO 60 & $26,8(14)$ & $51(14)$ & SW a \\
\hline 17 & 2012-04-23 & Podzamcze (163 n) & brak danych & SO 55,65 & $13,0(12)$ & $57(12)$ & W c \\
\hline 18 & $2012-05-23$ & Oblęgorek (85 i) & 14.00 & JD 55 & $26,9(13)$ & $29(12)$ & $\mathrm{NE}$ a \\
\hline 19 & 2012-09-11 & Oblęgorek (152 g) & 15.04 & SO KO & $29,0(13)$ & $27(13)$ & SW a \\
\hline 20 & 2014-03-14 & Sojowa (133 g) & 13.00 & SO 57 & $15,3(12)$ & $26(12)$ & NW c \\
\hline 21 & 2014-03-30 & Oblęgorek (85 g) & 14.12 & JD 55 & $16,2(14)$ & $19(14)$ & $\mathrm{Sa}$ \\
\hline 22 & 2014-03-30 & Gruchawka (79 a) & 14.02 & SO 70 & $16,2(14)$ & $19(14)$ & $\mathrm{Sa}$ \\
\hline 23 & 2015-05-05 & Czartoszowy (81 a) & 15.30 & SO 82 & $23,9(14)$ & $46(13)$ & SE a \\
\hline 24 & 2015-07-05 & Oblęgorek (87 a) & 13.40 & SO 109 & $31,0(13)$ & $40(13)$ & $\mathrm{Sa}$ \\
\hline 25 & 2015-08-04 & Oblęgorek (91 d) & 16.33 & JD 75 & $31,5(13)$ & $30(13)$ & SE a \\
\hline 26 & $2015-08-24$ & Niewachlów (138f) & 15.00 & SO 50 & $26,9(13)$ & $37(13)$ & SE a \\
\hline 27 & $2015-08-28$ & Niewachlów (108 d) & 14.20 & SO KO & $32,4(13)$ & $32(13)$ & $\mathrm{Sa}$ \\
\hline 28 & 2015-09-14 & Niewachlów (137 i) & 8.25 & SO 56 & $17,5(8)$ & $66(8)$ & SE c \\
\hline 29 & $2016-06-30$ & Niewachlów (105 c) & 21.00 & SO 79 & $30,2(14)$ & $35(14)$ & SW a \\
\hline 30 & $2016-07-25$ & Niewachlów (133 c) & 17.30 & SO 79 & $28,5(15)$ & $40(15)$ & $\mathrm{Sa}$ \\
\hline 31 & 2016-08-31 & Sojawa (112 c) & 8.43 & JD 60 & $18,1(8)$ & $57(8)$ & NW a \\
\hline 32 & 2017-06-29 & Niewachlów (111f) & 13.14 & drzew. nie wydziel. & $27,7(13)$ & $42(13)$ & SW c \\
\hline 33 & 2017-08-07 & Oblęgorek (89 f) & 18.07 & SO 11 & $21,0(15)$ & $44(16)$ & $\mathrm{E}$ a \\
\hline 34 & 2017-08-08 & Oblęgorek (98 f) & 15.41 & SO 11 & $23,2(15)$ & $48(14)$ & SE a \\
\hline 35 & 2018-04-08 & Gruchawka (71 j) & 17.48 & SO 74 & $21,5(14)$ & $40(14)$ & $\mathrm{Sa}$ \\
\hline 36 & 2018-04-21 & Oblęgorek (86 z) & 18.03 & SO 94 & $24,8(12)$ & $37(14)$ & W a \\
\hline 37 & 2018-05-06 & Oblęgorek (98 d) & 17.00 & SO 57 & $19,6(14)$ & $36(16)$ & $\mathrm{NE} a$ \\
\hline 38 & $2018-05-28$ & Niewachlów (121 a) & 13.50 & SO 76 & $25,7(13)$ & $36(12)$ & SE a \\
\hline 39 & 2018-06-01 & Niewachlów (121 h) & 13.18 & SO 15 & $29,1(13)$ & $32(13)$ & SE a \\
\hline 40 & 2018-07-03 & Dobrzeszów (38 h) & 14.34 & SO 105 & $22,6(14)$ & $36(14)$ & $\mathrm{Nc}$ \\
\hline 41 & 2018-07-04 & Oblęgorek (157 c) & 13.12 & DB 100 & $26,5(12)$ & $28(12)$ & $\mathrm{Wa}$ \\
\hline 42 & 2018-10-13 & Oblęgorek (157 c) & 10.30 & JD 65 & $19,0(10)$ & $52(10)$ & NE a \\
\hline
\end{tabular}


Tabela 2. cd.

Table 2. continued

\begin{tabular}{|c|c|c|c|c|c|c|c|}
\hline $\begin{array}{l}\text { Lp. } \\
\text { No. }\end{array}$ & $\begin{array}{l}\text { Data pożaru } \\
\text { Fire date }\end{array}$ & $\begin{array}{c}\text { Leśnictwo (odzdział) } \\
\text { Forestry (sector) }\end{array}$ & $\begin{array}{l}\text { Godz. } \\
\text { zgłoszenia } \\
\text { Notification } \\
\text { time }\end{array}$ & $\begin{array}{c}\text { Drzewostan } \\
\text { i wilgotność ściółki } \\
\text { Forest stade } \\
\text { and duff moisture }\end{array}$ & $\begin{array}{c}\text { Tmax (godz.) } \\
\text { przed pożarem } \\
\text { Tmax (h) } \\
\text { before fire }\end{array}$ & $\begin{array}{c}\text { fmin (godz.) } \\
\text { przed pożarem } \\
\text { fmin (h) } \\
\text { before fire }\end{array}$ & $\begin{array}{c}\text { Sytuacja } \\
\text { synoptyczna } \\
\text { Synoptic } \\
\text { situation }\end{array}$ \\
\hline 43 & 2018-11-06 & Gruchawka (62 b) & 12.15 & JD 70 & $17,2(12)$ & $49(12)$ & $\mathrm{Sa}$ \\
\hline 44 & 2019-04-22 & Dąbrowa (59 f) & 10.28 & JD 65 & $13,4(10)$ & $59(10)$ & $\mathrm{Ea}$ \\
\hline 45 & 2019-04-22 & Dąbrowa (68 a) & 12.55 & SO 5 & $14,4(12)$ & $47(12)$ & SE a \\
\hline 46 & 2019-04-23 & Oblęgorek (98 g, 161 a) & 18.20 & SO 16 & $17,4(15)$ & $30(16)$ & SE a \\
\hline 47 & 2019-07-28 & Sojawa (151 g) & 15.15 & SO 90,4 & $31,7(15)$ & $33(15)$ & SE a \\
\hline 48 & 2019-08-28 & Niewachlów (137 a) & 17.41 & SO 73 & $29,8(14)$ & $45(14)$ & $\mathrm{Sa}$ \\
\hline 49 & 2019-09-01 & Podzamcze (203 h) & SO 18 & SO 18 & $29,3(15)$ & $46(14)$ & $\mathrm{Sa}$ \\
\hline
\end{tabular}

Objaśnienia/Explanations:

Tłustym drukiem oznaczono pożar średni Medium fire is marked in bold

\begin{tabular}{|c|}
\hline WIOSNA \\
\hline LATO \\
\hline JESIEŃ \\
\hline
\end{tabular}

\begin{tabular}{|c|c|c|}
\hline$<15 \%$ & $25,1-30,0^{\circ} \mathrm{C}$ & $30-49 \%$ \\
\hline $\begin{array}{c}\text { ściólka b.sucha/ } \\
\text { very dry duff }\end{array}$ & gorąco/hot & sucho/dry \\
\hline$>27 \%$ & $>30,0^{\circ} \mathrm{C}$ & $<30 \%$ \\
\hline $\begin{array}{c}\text { ściółka niepalna/ } \\
\text { non-flammable duff }\end{array}$ & upalnie/very hot $\quad$ b. sucho/very dry \\
\hline \multicolumn{2}{|c|}{} \\
brak danych/no data
\end{tabular}

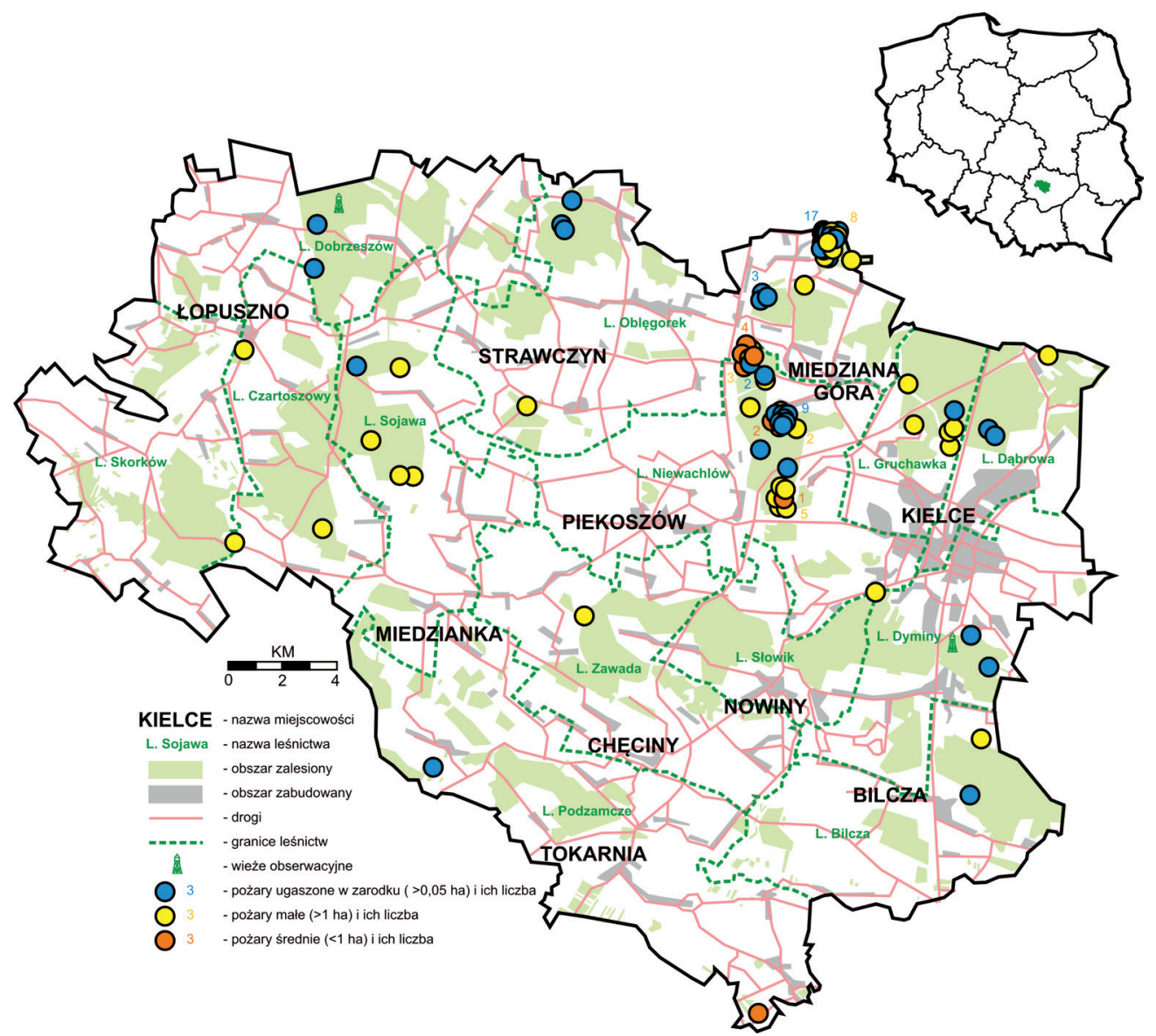

Ryc. 3. Lokalizacja pożarów lasów na terenie Nadleśnictwa Kielce w latach 2010-2019 (oprac. w oparciu o dane z http://www.bdl.lasy.gov.pl) Fig. 3. Location of forest fires in the Kielce Forest District in 2010-2019 (based on data from http://www.bdl.lasy.gov.pl) 


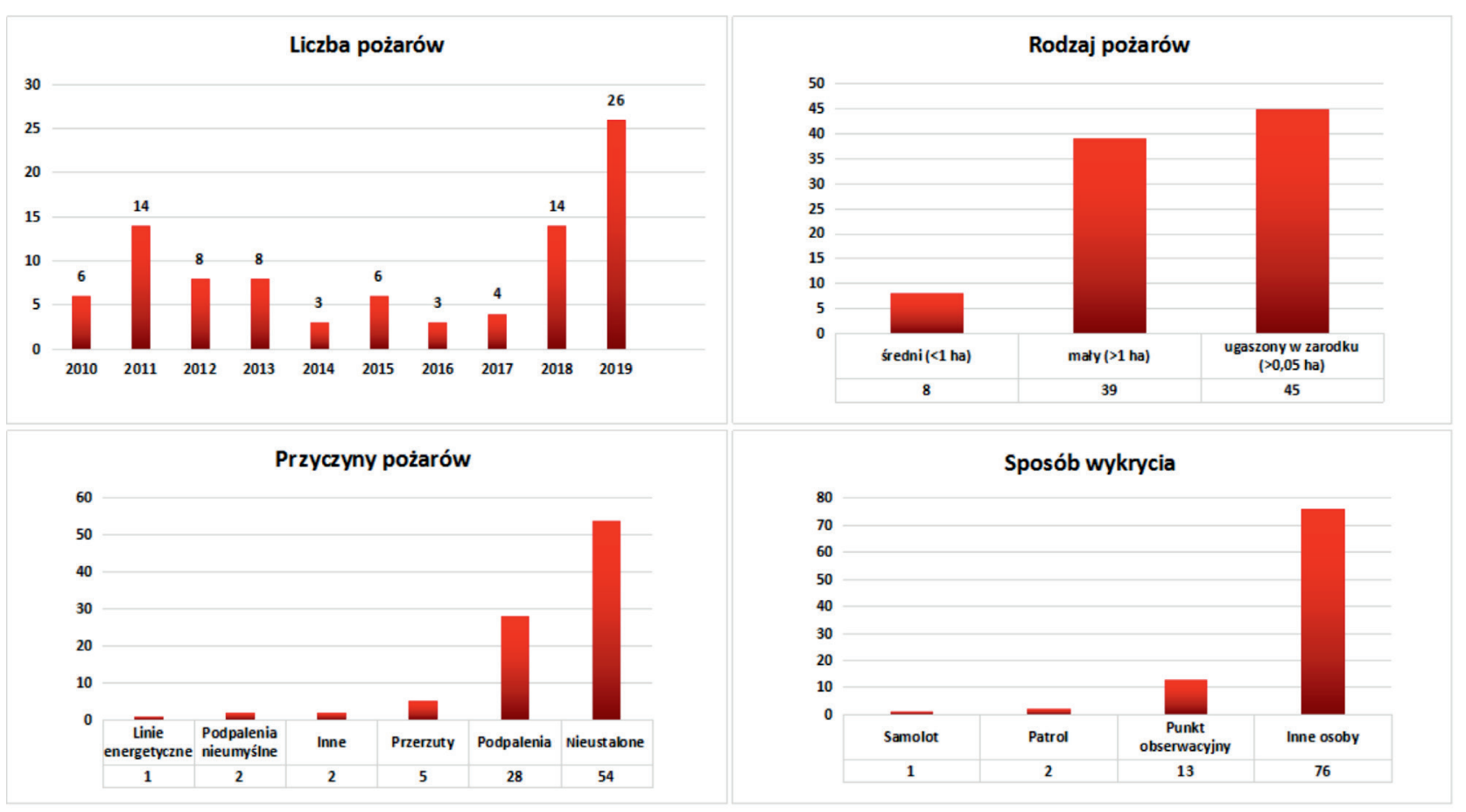

Ryc. 4. Sumaryczne dane dotyczące pożarów lasów w Nadleśnictwie Kielce w latach 2010-2019 (SILP, Llas.2)

Fig. 4. Summary data about forest fires in the Kielce Forest District in 2010-2019 (SILP, Llas.2)

Najwięcej zdarzeń wystąpiło w Leśnictwach Oblęgorek i Niewachlów, a najmniej, po jednym, w Leśnictwach Skorków i Zawada. Najczęściej pożary zostały zgłoszone przez inne osoby (76 przypadków), m.in. poprzez telefon na numer alarmowy, natomiast najmniej wykryły patrole naziemne (2 pożary) oraz samolot (1 pożar).

W analizowanym okresie aż w 54 przypadkach nie udało się ustalić przyczyny wybuchu pożaru. Ponadto rozpoznano 28 podpaleń, a także sytuacje wyjątkowe, jak wywołanie pożaru przez linie energetyczne.

\section{Pożary o nieustalonych przyczynach}

Zasadniczo pożary o nieustalonych przyczynach mogą wynikać z niefrasobliwości, nieostrożności, czy nawet z celowego działania człowieka. Przykładowo są to: rzucona zapałka lub niedopałek papierosa, niedogaszone ognisko lub iskry od przejeżdżających pojazdów. Ponieważ przyczyny te nie sposób zweryfikować, a sprawca może nawet nie wiedzieć, że podpalił las, w tym rozdziale starano się powiązać pożary o nieustalonych przyczynach z czynnikami występującymi bez udziału człowieka, tj. warunkami pogodowymi i zależną od nich wilgotnością ściółki.

Pogoda sprzyjająca pożarom stanowiła $43 \%$ wszystkich dni z pożarami o nieustalonych przyczynach. W sumie pożary o nieustalonych przyczynach wystąpiły w większości w sytuacjach antycyklonalnych $(83,6 \%)$ i przy adwekcji z sektora południowego $(77,6 \%)$. Najczęściej były to sytuacje SEa $(28,5 \%)$ i Sa $(22,4 \%)$. Z dużym prawdopodobieństwem można stwierdzić, że pożary o nieustalonych przyczynach w ponad połowie przypadków były związa- ne z napływem bardzo ciepłej i suchej masy powietrza zwrotnikowego. Masa ta powoduje szybkie wysychanie ściółki leśnej.

W rozpatrywanym dziesięcioleciu pożary o nieustalonych przyczynach wystąpiły w każdym roku, z wyjątkiem 2013. Najwięcej, bo 12 w roku 2011 i 10 w roku 2018. W sumie na okres miesięcy letnich (VI-VIII) przypadło $44,9 \%$ pożarów o nieustalonych przyczynach (Tab. 2). Na okres wiosenny (III-V) przypadło aż 42,9\% pożarów o niezidentyfikowanych przyczynach, natomiast na jesienny (IX-XI) tylko 12,2\%. Wiosenne pożary wynikały w dużej mierze z najniższej w roku wilgotności względnej powietrza (Żarnowiecki 1991; Krzyżewska i in. 2017). Najwcześniej pożar o nieustalonych przyczynach zgłoszono 25 marca 2011 roku w Leśnictwie Bilcza, a najpóźniej 6 listopada 2018 roku w Leśnictwie Gruchawka (Tab. 2). W Nadleśnictwie Kielce warunki sprzyjające pożarom o nieustalonych przyczynach odnotowano w bardzo suche dni kwietnia roku 2011 (Leśnictwa Gruchawka, Oblęgorek - pożar średni i Niewachlów - pożar średni), a także w maju 2012 (Oblęgorek) i w marcu 2014 (Leśnictwa Sojawa, Oblęgorek i Gruchawka, Tab. 2).

W każdym dniu, poza 31 sierpnia 2016 roku, gdy zabrakło pomiaru południowego, wilgotność ściółki z godziny 13:00 była niższa od tej z godziny 8:00 (Ryc. 5). Wskazuje to pośrednio na brak opadu między tymi terminami. Również dane obserwacyjne ze stacji synoptycznej Kielce-Suków nie wskazują na wystąpienie opadu w dniach i okresach przed zgłoszeniem pożaru. Wzrost temperatury powietrza i spadek wilgotności względnej prowadził do spadku wilgotności ściółki, do czego przyczyniał się również wzrost promieniowania i prędkości wiatru. Dlatego 
tak ważne staje się określenie warunków pogodowych tuż przed pożarem.

Okazało się, że sprzyjające warunki termiczno-wilgotnościowe przy bardzo suchej ściółce występowały przy 15 pożarach o nieustalonej przyczynie $(30,6 \%)$. W roku 2010 dotyczyło to trzech pożarów (Leśnictwa Niewachlów, Dobrzeszów, Oblęgorek) i jeden raz w roku 2012 (Leśnictwo Oblęgorek). W roku 2015 zdarzyło się ich 4 (po 2 w Leśnictwach Oblęgorek i Niewachlów) i wszystkie związane były z falami letnich upałów, jakie przechodziły wtedy przez Polskę (Sulikowska i in. 2016). Dni gorące i upalne wystąpiły również podczas pożaru w lecie $2016 \mathrm{r}$. (Leśnictwo Niewachlów), wiosną i latem 2018 r. (Leśnictwo Niewachlów - latem pożar średni) i 3 razy w roku 2019 (Leśnictwa: Sojawa, Niewachlów - pożar średni, Podzamcze, Tab. 2).

Niepalna ściółka wystąpiła tylko w sześciu terminach pożarów (12,8\%), co wskazuje na celowe podpalenie lasu ( $5 \mathrm{z}$ nich to Leśnictwo Oblęgorek, jeden Podzamcze). W 16 przypadkach (34\%) pożar zarejestrowano przy ściółce, która nie była zbyt sucha (16-27\%), ale mogła zająć się ogniem wskutek celowego lub przypadkowego podpalenia. Zwłaszcza te ostatnie mogły zdarzyć się, gdy ściółka miała wilgotność mniejszą od 15\%. Takich terminów było 26, co stanowi 55,3\% niezidentyfikowanych pożarów. Jeżeli chodzi o drzewostany, to w 21 przypadkach (80\%) były to bory sosnowe, w trzech (12\%) bory jodłowe i w jednym grąd dębowy. Ponieważ zespoły borowe odznaczają się dużą zawartością lotnych substancji łatwopalnych w ściółce, zainicjowanie zapłonu, nawet pojedynczą iskrą, może doprowadzić do gwałtownego pożaru lasu.

Na 49 pożarów o niezidentyfikowanych przyczynach w jednym przypadku nie ustalono rodzaju drzewostanu (Tab. 2). Wśród określonych, aż 32 zbiorowiska $(66,6 \%)$ stanowiły bory sosnowe, 10 bory jodłowe $(20,8 \%), 4$ bory mieszane $(8,3 \%)$ i po 1 dąbrowy i olszyny $(2,1 \%)$. Zdecydowana większość $95,8 \%$ pożarów o nieustalonych przyczynach wystąpiła więc w drzewostanach borowych, gdzie ściółka była najbardziej łatwopalna.

Niestety, ze względu na bardzo lokalny charakter występowania burz, a zwłaszcza piorunów, ustalenie takiej przyczyny dla Nadleśnictwa Kielce jest bardzo trudne. Wzięto pod uwagę warunki meteorologiczne panujące na synoptycznej stacji Kielce-Suków, ale nie stwierdzono w żadnym przypadku chmur burzowych Cumulonimbus z opadami w terminach pożarów o nieustalonych przyczynach. Oczywiście takiej możliwości nie można całkowicie wykluczyć, choć jest ona bardzo mało prawdopodobna, szczególnie po przeanalizowaniu warunków termiczno-wilgotnościowych i cyrkulacyjnych (fronty atmosferyczne). Nie ma przesłanek do stwierdzenia, że piorun był przyczyną jakiegokolwiek pożaru o nieustalonej przyczynie w Nadleśnictwie Kielce w rozpatrywanym dziesięcioleciu.

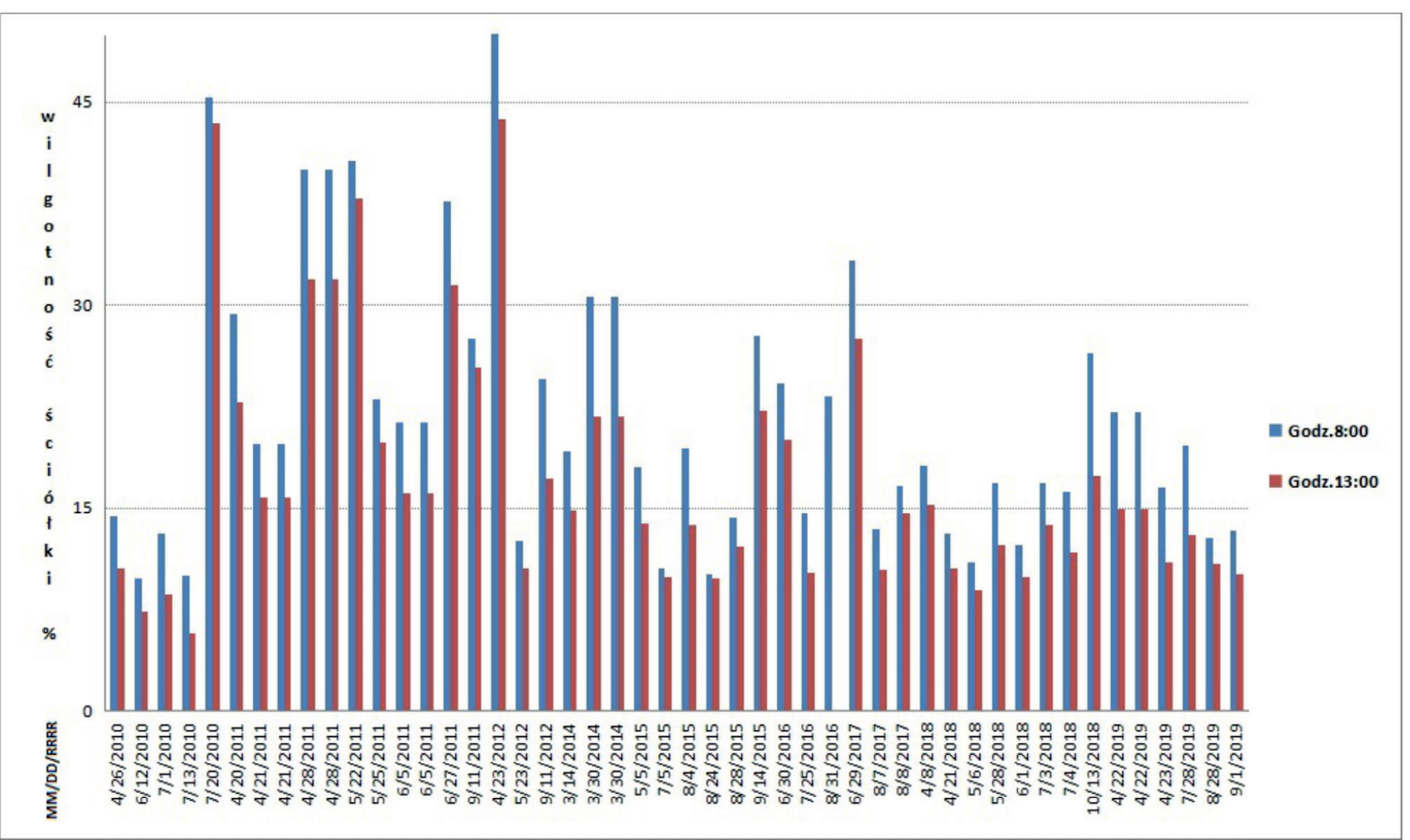

Ryc. 5. Wilgotność ściółki w \% w dwóch terminach obserwacyjnych z dni pożarów o niezidentyfikowanych przyczynach. Dane pozyskane ze stacji Jędrzejów (las) (http://www.traxelektronik.pl)

Fig. 5. The duff moisture in \% in two observation dates from days of fires with unidentified causes. Data obtained from the Jędrzejów (Forest) station (http://www.traxelektronik.pl) 


\section{System ochrony przeciwpożarowej}

W Polsce na terenie Lasów Państwowych funkcjonuje system ochrony przeciwpożarowej, którego zadaniem jest szybkie wykrycie i ugaszenie pożaru zanim dojdzie do jego rozprzestrzenienia na terenie kompleksu leśnego lub terenu bezpośrednio przylegającego do lasu. W tym celu prowadzona jest w okresie zagrożenia pożarowego (wiosna, lato i wczesna jesień) obserwacja za pomocą wież pożarowych, patroli naziemnych oraz Punktów Alarmowo-Dyspozycyjnych (PAD). Na terenie każdego nadleśnictwa znajdują się także inne elementy infrastruktury, które mają służyć do zwalczania pożarów lasów (drogi pożarowe, punkty czerpania wody, Leśne Bazy Lotnicze).

Centralnym elementem nadzorującym obserwacje przeciwpożarowe jest PAD, który znajduje się w każdym nadleśnictwie $w$ Polsce. Do tego miejsca kierowane są wszystkie zawiadomienia o pożarach lasów: poprzez telefony alarmowe (widniejący na tablicach alarmowych przy drogach prowadzących przez tereny zalesione) od okolicznych mieszkańców zgłaszających pożar lasu, zgłoszenia o podejrzanych dymach dostrzeżonych z wież obserwacyjnych lub patroli naziemnych. Precyzyjna lokalizacja wystąpienia ewentualnego pożaru wymaga koordynacji co najmniej dwóch wież obserwacyjnych (Ryc. 6) i PAD, do którego wysyłane są namiary widocznego dymu. Wieże obserwacyjne nie są przypisane wyłącznie do nadleśnictwa, na terenie którego się znajdują i często obserwatorzy współpracują ze sobą na pograniczu dwóch nadleśnictw. Obserwator znajdujący się na wieży zgłasza do PAD informacje i lokalizacje domniemanego pożaru lasu. Informacje te są weryfikowane przez przynajmniej jeszcze jednego obserwatora z innej wieży. Podane przez obserwatorów współrzędne są wprowadzane na mapę nadleśnictwa, co pozwala na precyzyjne ustalenie miejsca zagrożonego pożarem, do którego wysyłany jest patrol naziemny. W zależności od sytuacji, patrol zgłasza do PAD pożar i może podjąć samodzielną akcję gaśniczą. Jeżeli pożar jest zbyt duży, PAD kieruje zgłoszenie do straży pożarnej. W przypadku dużego pożaru lub utrudnionego dostępu do zagrożonego obszaru leśnego, wysyłane jest zgłoszenie do Regionalnej Dyrekcji Lasów Państwowych (RDLP) z prośbą o zrzut powietrzny, tj. poprzez wysłanie samolotów gaśniczych typu Dromader lub śmigłowców) (http://www.katowice.lasy.gov.pl). Po zakończonej akcji gaśniczej sporządzany jest protokół z pożaru, w którym podawane są informacje o stratach, rozmiarze pożaru, ilości jednostek gaśniczych itp. Dane te są wprowadzane do systemu „SILP, Llas.2", z którego pozyskano analizowane w tym artykule parametry.

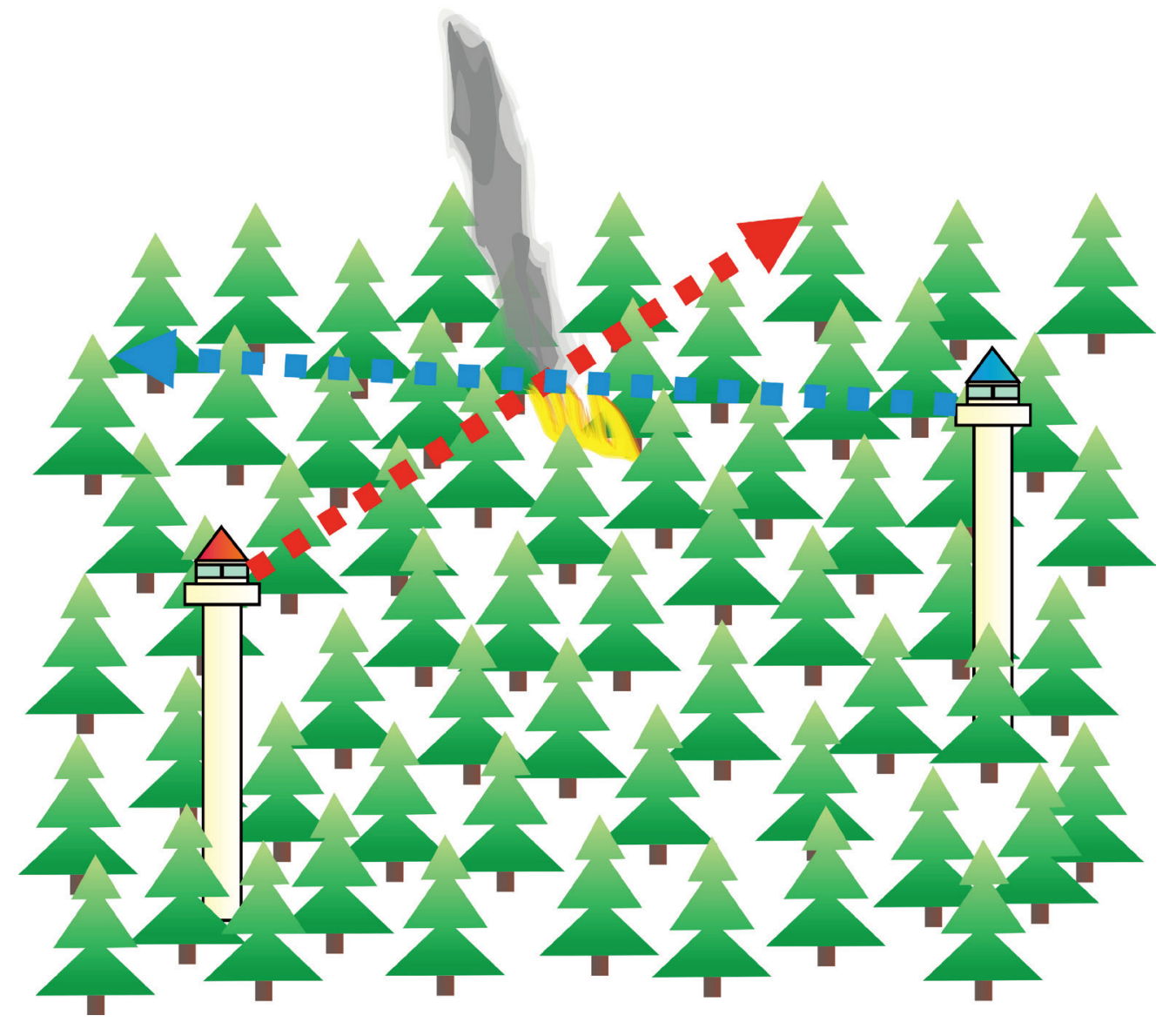

Ryc. 6. Sposób lokalizacji pożaru za pomocą wież obserwacyjnych Fig. 6. Fire localization method using observation towers 
Szczegółowa analiza danych z tego systemu dla Nadleśnictwa Kielce pozwoliła ustalić czas reakcji od momentu zgłoszenia pożaru do przystąpienia do akcji gaśniczej. Najkrótszy czas reakcji mieścił się w przedziale 5-10 minut, jednak zdarzały się sytuacje, kiedy czas reakcji wynosił 0 lub miał wartości ujemne. W tym pierwszym przypadku przyczyną takiej sytuacji jest bezpośrednie przystąpienie do akcji gaśniczej przez patrol naziemny, który wykrył i zgłosił pożar. W przypadku wartości ujemnych może być związane z powiadomieniem przez mieszkańców o pożarze lasu najpierw straży pożarnej, a dopiero później Lasów Państwowych. W takich sytuacjach na miejscu pożaru prowadzona jest już akcja gaśnicza, a do PAD dopiero dociera zgłoszenie. Trzeba też tego typu dane rozpatrywać pod kątem zwykłego błędu, który pojawił się w raportach. Najdłuższy czas reakcji wynosi 66 minut, natomiast średni czas reakcji po zgłoszeniu pożaru to ok. 9 minut (SILP, Llas.2).

Najkrócej trwająca akcja gaśnicza trwała od 0 do 20 minut. Krótki czas gaszenia ponownie może być związany z wykryciem pożaru przez patrol naziemny, który na miejscu rozpoczął akcję gaśniczą lub należy rozpatrywać niektóre dane jako błędne. Najdłużej trwająca akcja gaśnicza trwała 580 minut. Średni czas gaszenia pożaru wyniósł ok. 118 minut (SILP, Llas.2).

Rozmieszczenie miejsc występowania pożarów (Ryc. 3) na terenie nadleśnictwa pokazuje rejony o wyższym poziomie zagrożenia. Są to obszary w pobliżu dużych miejscowości (Kielce, Miedziana Góra) w północno-wschodniej części nadleśnictwa. Również w leśnictwach Oblęgorek i Niewachlów zlokalizowano duże skupiska różnych typów pożarów, które pojawiają się niemal w każdym roku w okresie prowadzenia pomiarów. Wszystkie odnotowane pożary lasów występowały na obrzeżach kompleksów leśnych, rzadziej w środku lasu. W miejscach największej liczby pożarów następowały tak zwane przerzuty i ponowne zaprószenie ognia na sąsiednich pododdziałach (czego efektem była większa liczba raportów, które należało wiązać z jednym zdarzeniem). Na obszarze Leśnictwa Oblęgorek dominowały pożary małe oraz gaszone w zarodku i pojawiały się one w obrębie jednego kompleksu leśnego. W Leśnictwie Niewachlów doszło do podobnej liczby pożarów małych i gaszonych w zarodku, ale także odnotowano największą liczbę pożarów średnich, które przekraczały 2 ha powierzchni. Największy pożar, który objął ponad 3,2 ha został wykryty przez patrol na terenie Leśnictwa Podzamcze w obrębie niewielkiego kompleksu leśnego (Ryc. 3).

\section{Dyskusja}

Obszar Nadleśnictwa Kielce charakteryzuje się brakiem zwartego kompleksu leśnego. Liczne, mniejsze kompleksy leśne i zagajniki tworzą mozaikę z wylesionymi terenami zagospodarowanymi przez człowieka. Ułatwia to dostęp do obszarów leśnych i jest głównym czynnikiem prowa- dzącym do powstawania zagrożeń pożarowych. Dane wyraźnie wskazują na znaczącą przewagę czynnika antropogenicznego jako głównego źródła pożarów lasów w tym regionie. Dla wielu pożarów nie udało się ustalić przyczyn ich powstania, lecz ich rozmieszczenie na obrzeżach kompleksów leśnych w bliskiej odległości od zabudowań sugeruje, że działalność antropogeniczna była w tych przypadkach dominująca.

Rozproszenie obszarów leśnych i znaczne nasycenie nadleśnictwa punktami osadniczymi wpływa również na szybkie wykrywanie i gaszenie licznych, niewielkich pożarów zanim dojdzie do ich rozwinięcia. Były one szybko wykrywane głównie przez wieże obserwacyjne oraz mieszkańców pobliskich miejscowości.

Szczególną uwagę należy zwrócić przy analizie danych pogodowych na kwiecień, gdyż w tym miesiącu w latach 2010-2019 dochodziło najczęściej do pożarów lasów. Dane ze stacji w Jędrzejowie (Ryc. 2) pokazują wyraźne zmiany średniej miesięcznej temperatury powietrza $5 \mathrm{~cm}$ nad gruntem w poszczególnych latach, np. w czerwcu 2019 r. była ona wyższa, natomiast w kwietniu 2012 r. niższa niż w pozostałych latach. Rokrocznie w okresie letnim średnia miesięczna temperatura przekracza $20^{\circ} \mathrm{C}$, a w latach najczęstszych pożarów lasów (2012 i 2019) osiągała nawet $24^{\circ} \mathrm{C}$. Systematyczny spadek średniej wilgotności ściółki następuje co roku, a najniższe wartości miesięczne w okresie letnim w 2013 i 2019 roku wynosiły poniżej $20 \%$.

Lata 2018 i 2019 wyróżniają się największą liczbą pożarów lasów w okresie prowadzenia pomiarów (Ryc. 4), w tym aż 3 pożary średnie miały miejsce w 2018 roku. Wpływ na to mogły mieć znacznie niższe opady w kwietniu 2018 roku i wyższe temperatury powietrza (średnia miesięczna) względem poprzednich lat (Tab. 1). Pożary w 2018 roku występowały przeważnie na początku maja i w czerwcu (nieco wyższe opady, ale również wyraźnie wyższe temperatury średnie powietrza), co było prawdopodobnie długofalowym skutkiem warunków pogodowych z kwietnia, gdyż ponowne uzyskanie wilgotności w granicach norm bezpieczeństwa zarówno przez glebę leśną, jak i przesuszoną ściółkę wymaga czasu. Najwięcej pożarów, ale niewielkich, występowało w 2019 roku, pomimo wyraźnego wzrostu średniej opadów i obniżenia temperatury powietrza dla kwietnia.

Zwiększaniu liczby pożarów w kolejnych latach może sprzyjać wyraźny wzrost średnich rocznych temperatur powietrza. Na liczbę pożarów nie wpływa liczba dni upalnych, np. z 24 takimi dniami w 2015 roku doszło do zaledwie 6 pożarów. Niewykluczone jest, że może być to efekt wprowadzania zakazów wejść do lasów, kiedy przy niekorzystnych warunkach pogodowych wilgotność ściółki jest niebezpiecznie niska, co zresztą widać dla danych z sierpnia 2015 roku (Ryc. 5).

Wśród pożarów o niezidentyfikowanych przyczynach praktycznie wykluczono wyładowania atmosferyczne. 


\section{Wnioski}

Dane dla okresu 2010-2019 z Nadleśnictwa Kielce wskazują na wzrost liczby pożarów w kolejnych latach. Najwięcej pożarów miało miejsce w latach 2018-2019, a najmniej w 2014-2017. W przeważającej liczbie są to pożary wywołane przez człowieka lub o niezidentyfikowanej przyczynie (podpalenia?). Przeważającą liczbę stanowią małe pożary oraz ugaszone w zarodku. Pojawiają się one corocznie w tych samych miejscach, w pobliżu zabudowań i dróg, co może wskazywać na ich antropogeniczną przyczynę, bezpośrednią lub pośrednią.

Wywołane 3 z 8 większych pożarów (średnie) w 2018 roku, kiedy wilgotność ściółki była wyraźnie niższa niż w latach poprzednich, były związane z niekorzystnymi warunkami meteorologicznymi, jakie wystąpiły w tym roku, zwłaszcza w kwietniu. Zazwyczaj o tej porze roku dochodzi też do najczęstszych podpaleń wywołanych, np. wypalaniem traw w pobliżu obszarów leśnych. Niewykluczony jest też wpływ stopniowego ocieplania się klimatu (wzrost średniej i średniej maksymalnej temperatury powietrza w latach 2010-2019), a także bardzo suchy i ciepły rok 2018, który wraz z suchymi i ciepłymi zimami doprowadził do osuszenia ściółki. Nagromadzenie tych niekorzystnych zmian oraz czynnik ludzki mógł być przyczyną wzrostu liczby pożarów w roku 2018 i 2019.

Pożary o niezidentyfikowanych przyczynach w rozpatrywanym dziesięcioleciu wystąpiły w większości w zbiorowiskach borowych, zwłaszcza w najbardziej palnych borach sosnowych. Ich przyczyny miały charakter głównie antropogeniczno-naturalny. Spowodowane były jednoczasowym wystąpieniem silnych właściwości palnych leśnej ściółki, sprzyjających warunków pogodowo-synoptycznych oraz zaprószeniem ognia przez człowieka. Z dużym prawdopodobieństwem można przyjąć, że zainicjowany przez człowieka przypadkowy zapłon leśnej ściółki wystąpił w około połowie pożarów o nieustalonej przyczynie. W pozostałych należy szukać przyczyn w celowym podpaleniu z uwagi na wysoką wilgotność ściółki. Wśród pożarów o niezidentyfikowanych przyczynach praktycznie wykluczono wyładowania atmosferyczne.

Skuteczność zwalczania pożarów lasów na terenie Nadleśnictwa Kielce w analizowanych latach była bardzo duża. Czas reakcji na zgłoszenie i ugaszenie pożaru był krótki, co wiąże się z bardzo dobrą koordynacją służb oraz ułatwionym dojazdem do większości badanego obszaru, co wynika z rozbudowanej sieci drogowej i brakiem większych, zwartych kompleksów leśnych.

\section{Podziękowania}

Serdeczne podziękowania kierujemy do Nadleśniczego Nadleśnictwa Kielce, Pana Roberta Płaskiego, który umożliwił uzyskanie danych, na podstawie których przygotowano powyższe badania. Również szczególne podziękowania autorzy kierują do Panów Bartosza Bysieckiego i Piotra Przepióry za pomoc przy pozyskaniu i przetwarzaniu m.in. raportów pożarowych, jak również za niezwykle ważną pomoc merytoryczną.

\section{Literatura}

Bogacz, A., Jędo, M., Woźniczka, P., 2011. Właściwości silnie przesuszonych organicznych gleb popożarowych obiektu Sobin-Jędrzychów. Woda-Środowisko-Obszary Wiejskie 11, 4 (36), 43-56.

Bogacz, A., Łabaz, B., Woźniczka, P., 2014. Właściwości gleb organicznych popożarowych obszarów leśnych na przykładzie obiektu MikorzyceGórowo. Woda-Środowisko-Obszary Wiejskie 14, 4 (48), 5-16.

Certini, G., 2005. Effects of fire on properties of forest soils: A review. Oecologia 143, 1-10.

Ciura, T., 2018. Przyczyny i źródła wybuchu pożarów leśnych w Szwecji. Monitor Leśny.

Dickman, K., 2020. Groźny dym z pożarów. Świat Nauki 4 (344), 28-35.

Dumontet, S., Dinel, H., Scopa, A., Mazzatura, A., Saracino, A., 1996. Post-fire soil microbial biomass and nutrient content of a pine forest soil from a Dunal Mediterranean environment. Soil Biology and Biochemistry 28 (10/11), 1467-1475.

Feurdean, A., Vannière, B., Finsinger, W., Warren, D., Connor, S.C., Forrest, M., Liakka, J., Panait, A., Werner, C., Andric, M., Bobek, P., Carter, V.A., Davis, B., Diaconu, A.C., Dietze, E., Feeser, I., Florescu, G., Gałka, M., Giesecke, T., Jahns, S., Jamrichová, E., Kajukało, K., KapIan, J., Karpinska-Kołaczek, M., Kołaczek, P., Kuneš, P., Kupriyanov, D., Lamentowicz, M., Lemmen, C., Magyari, E.K., Marcisz, K., Marinova, E., Niamir, A., Novenko, E., Obremska, M., Pędziszewska, A., Pfeiffer, M., Poska, A., Rösch, M., Słowinski, M., Stancikaite, M., Szal, M., Swięta-Musznicka, J., Tantau, I., Theuerkauf, M., Tonkov, S., Valkó, O., Vassiljev, J., Veski, S., Vincze, I., Wacnik, A., Wiethold, J., Hickler, T., 2020. Fire hazard modulation by long-term dynamics in land cover and dominant forest type in eastern and central Europe. Biogeosciences 17, 1213-1230.

Fraszewski, D., 1994. Kierunki zagospodarowania terenów po wielkich pożarach lasów, Raport IBL. Warszawa.

Gallagher, M.R., Skowronski, N.S., Lathrop, R.G., McWilliams, T., Green, E.J., 2020. An Improved Approach for Selecting and Validating Burn Severity Indices in Forested Landscapes. Canadian Journal of Remote Sensing, http://dx.doi.org/10.1080/07038992.2020.1735931

Haze, M., Widłaszewska, B., Kijewska, B., 2012. Instrukcja ochrony przeciwpożarowej lasu. Ośrodek Rozwojowo-Wdrożeniowy Lasów Państwowych w Bedoniu.

Jones, J.C., Ramahti, H., Fowler, D., Vorasurayakarn, J., Bridges, R.G., 1990. The Self-Heating and Thermal Ignition Propensity of Forest Floor Litter. Journal of Fire Sciences 8 (3), 207-223.

Kaczmarowski, J., 2016. Pirologia leśna. Przegląd Pożarniczy 7, 25-29.

Karlikowski, T., Łonkiewicz, B., 1975. Badania i ustalenie kryteriów oceny zagrożenia pożarowego lasu w oparciu o warunki meteorologiczne i skład gatunkowy drzewostanu, Raport IBL. Warszawa.

Karlikowski, T., Parzuchowska, J., Sakowska, H., Zając, S., 1998. Ocena ekonomiczna strat spowodowanych przez pożary w Polsce w latach 1991-1995. Postępy Techniki w Leśnictwie 68, 52-58, SliTLiD, Warszawa.

Kondracki, J., 1977. Regiony fizycznogeograficzne Polski. Wydawnictwo Uniwersytetu Warszawskiego, Warszawa.

Kondracki, J., 2002. Geografia regionalna Polski. Wydawnictwo Naukowe PWN, Warszawa.

Kreye, J.K., Varner, M.J., Dugaw, C.J., Cao, J., Szecsei, J., Engber, E.A., 2013. Pine cones facilitate ignition of forest floor duff. Canadian Journal of Forest Research 43, 512-516.

Krzyżewska, A., Wereski, S., Dobek, M., 2017. Wilgotność względna i dni charakterystyczne w Lublinie w latach 1951-2015. Annales UMCS $72(2), 27-39$.

Kutiel, P., Shaviv, A., 1992. Effects of soil type, plant composition and leaching on soil nutrients following a simulated forest fire. Forest Ecology and Management 53, 329-343.

Marchelek, M., 2020. Zagrożenie pożarowe w Lasach. Lasy Państwowe. Nadleśnictwo Kościan, https://koscian.poznan.lasy.gov.pl/zagrozenie-pozarowe\#.X2Ne5NSLS9I

McClure, C.D., Jaffe, D.A., 2018. U.S. particulate matter air quality improves except in wildfire-prone areas. Proceedings of the National Academy of Sciences USA 115(31), 7901-7906. 
Miller, J.D., Thode, A.E., 2007. Quantifying burn severity in a heterogeneous landscape with a relative version of the delta Normalized Burn Ratio (dNBR). Remote Sensing of Environment 109, 66-80.

Niedźwiedź, T., 1981. Sytuacje synoptyczne i ich wpływ na zróżnicowanie przestrzenne wybranych elementów klimatu w dorzeczu górnej Wisły. Rozprawy Habilitacyjne UJ 58, 1-159, Kraków.

Nurzyńska-Wierdak, R., 2015. Aktywność biologiczna olejków eterycznych roślin z rodziny Pinaceae. Annales UMCS 25 (3), 19-31.

Odion, D.C., Davis, F.W., 2000. Fire, soil heating and formation of vegetation patterns in Chaparral. Ecological Monographs 70 (1), 149-169.

Parminter, J., 1983. Fire-ecological relationships for the biogeoclimatic zones of the Cassiar Timber supply area. Northern Fire Ecology Project. Protection Branch Ministry of Forests, Victoria, B.C.

Pierce, J.L., Meyer, G.A., Thackray, G.D., Wood, S.H., Lundeen, K., Borgert J.A., Rothwell, E., 2004. Fire and Ice in Central Idaho: Modern and Holocene Fires, Debris Flows and Climate in the Payette River Basin and Quaternary and Glacial Geology in the Sawtooth Mountains. Open-File Report 2004-1222. U.S. Department of the Interior, U.S. Geological Survey.

Preston, C.A., Baldwin, I.T., 1999. Positive and negative signals regulate germination in the post-fire annual, Nicotiana attenuata. Ecology 80 (2), 481-494.

Prunicki, M., Kelsey, R., Lee, J., Zhou, X., Smith, E., Haddad, F., Wu, J., Nadeau, K., 2019. The impact of prescribed fire versus wildfire on the immune and cardiovascular systems of children. Allergy 74 (10), 1989-1991.

Przepióra, P., Król, G., Frączek, M., Kalicki, T., Kłusakiewicz, E., 2017. Lokalizacja i interpretacja osadów po pożarach lasów - studium przypadku. Acta Universitatis Lodziensis. Folia Geographica Physica 16, 43-49.

Pyne, S.J., 2015. Between two fires: A fire history of contemporary America. University of Arizona Press.

Sakowska, H., 1994. Człowiek przyczyną ognia w lesie. Teczka Leśnego Prelegenta 10, 4-7, ZG SITLiD, Warszawa.

Santorski, Z., 1994a. Rejonizacja zagrożenia pożarowego lasów w Polsce. Rozprawa doktorska, maszynopis, Warszawa.

Santorski, Z., 1994b. Jaki las się łatwiej pali? Teczka Leśnego Prelegenta 10, 8-11, ZG SITLiD, Warszawa.

Santorski, Z., 1999. Prognozowanie zagrożenia pożarowego lasów. Metoda IBL. Biblioteczka Leśniczego 112, SIiTLiD, DGLP, Warszawa.

Santorski, Z., Mycke-Dominko, M., 1998. Katastrofalne pożary lasów - monitoring teledetekcyjny. Postępy Techniki w Leśnictwie 68, SliTLiD, Warszawa.

Sikorska, E., 2004. Siedliskowe podstawy hodowli lasu. Ośrodek Rozwojowo-Wdrożeniowy Lasów Państwowych, Warszawa.

Sulikowska, A., Wypych, A., Woszczek, I., 2016. Fale upałów latem 2015 roku i ich uwarunkowania cyrkulacyjne. Badania Fizjograficzne 7 , Seria A: Geografia Fizyczna (A67), 205-223.

Szczygieł, R., 1977. Wpływ turystyki na zagrożenie pożarowe lasów i metody zapobiegania. Las Polski 4, Warszawa.

Szczygieł, R., 1982. Planning, Organization and Techniques of Forest Fire Control by means of Ground Equipment. Forest Fire Prevention and Control, Proceedings of an International Seminar org. by the Timber Committee of the UN, EC for Europe, Warsaw 20-22 May 1981, Hague; Martinus Nijhoff/Dr W. Junk Publishere, 127-134.

Szczygieł, R., 1985. Badanie czynników kształtujących powstawanie i rozprzestrzenianie się pożarów leśnych oraz doskonalenie metod zwalczania pożarów leśnych. IBL, Warszawa.
Szczygieł, R., 1987. Kryteria oceny prognozowania zagrożenia pożarowego lasów. Postępy Techniki w Leśnictwie 41, SliTLiD, Warszawa.

Szczygieł, R., 1988. Organizacja, taktyka i technika zwalczania pożarów lasu. Dokumentacja IBL, maszynopis, Warszawa.

Szczygieł, R., 1989. Rozprzestrzenianie się pożaru pokrywy gleby leśnej - próba modelowania. Rozprawa doktorska, maszynopis, Warszawa.

Szczygieł, R., 1991a. The influence of weather factors on forest fire risk. Proceedings of Seminar of Forest Fire Prevention, Land, Use and People. Athens, Greece 27.10-3.11.1991, Seminar ECE/FAO/ILO, Published by MInistry of Agriculture Secretariat General for Forest and National Enviorment.

Szczygieł, R., 1991b. Warunki meteorologiczne a pożary lasu. Zeszyty Naukowe Szkoły Głównej Służby Pożarniczej 1, Warszawa.

Szczygieł, R., 1991c. A model of forest fire. 10eme Congres Forestier Mondial, Proceedings Actas 2, Paris.

Szczygieł, R., 1992. Modelowanie pożarów leśnych. Przegląd Pożarniczy 5, Warszawa.

Szczygieł, R., 2010. Warunki kształtujące powstawanie i rozprzestrzenianie się pożarów lasu. Kampania informacyjna pt. „Ogień w lesie a przyroda - podniesienie świadomości mieszkańców terenów wiejskich w zakresie zapobiegania pożarom lasów", Warszawa 20.09.2010, 1-35.

Szczygieł, R., 2012. Wielkoobszarowe pożary lasów w Polsce. Bezpieczeństwo i Technika Pożarnicza 1, 67-78, CNBOP-PIB.

Szczygieł, R., Ubysz, B., Kwiatkowski, M., Piwnicki, J., 2007. Kategoryzacja zagrożenia pożarowego lasów, Raport IBL (II etap). Sękocin Stary.

Szczygieł, R., Ubysz, B., Kwiatkowski, M., Piwnicki, J., 2008. Kategoryzacja zagrożenia pożarowego lasów Polski, Raport IBL (III etap). Sękocin Stary.

Ubysz, B., 1992. Pożary i ich skutki w środowisku leśnym. Postępy Techniki w Leśnictwie 52, 73-79, SliTLiD, Warszawa.

Ubysz, B., 1994. Ekologiczne następstwa pożaru lasu. Teczka Leśnego Prelegenta 10, ZG SliTLiD, Warszawa.

Wiłkomirski, B., Gutry, P., 2010. Zmiany przyrodnicze w ekosystemach pod wpływem pożarów środowiskowych. Rocznik Świętokrzyski, Seria B: Nauki Przyrodnicze 31, 95-110.

Wiśniewski, W., 2001. Organizacja i technologia gaszenia pożarów lasu. SA PSP, Poznań

Xue, L., Li, Q., Chen, H., 2014. Effects of a Wildfire on Selected Physical, Chemical and Biochemical Soil Properties in a Pinus massoniana Forest in South China. Forests 5, 2947-2966.

Żarnowiecki, G., 1991. Wpływ ekosystemów leśnych na wilgotność względną powietrza w Białowieskim Parku Narodowym. Wydział Geografii i Studiów Regionalnych, Uniwersytet Warszawski, 1-149.

Żarnowiecki, G., 1994. Ocena stosunków wilgotnościowych powietrza w zbiorowiskach leśnych. Przegląd Geofizyczny 39 (2), 179-184.

\section{Źródła internetowe}

http://www.bdl.lasy.gov.pl

http://www.danepubliczne.imgw.pl

http://www.katowice.lasy.gov.pl/ochrona-przeciwpozarowa

http://www.kielce.radom.lasy.gov.pl

http://www.knmi.nl

http://www.meteomodel.pl

http://www.traxelektronik.pl 